\title{
Carbon efficiency estimation of residential products
}

\author{
SuxianZhang ${ }^{1, a}$, XinyanLiü \\ ${ }^{1}$ School of Management,Xi'an university of architecture and technology,Xi'an 710055,China \\ azsxzds@126.com, ${ }^{\mathrm{b}}$ Ixybd830@163.com
}

Keywords: residential product; life cycle; carbon emission; carbon efficiency

\begin{abstract}
Residential products impact on the ecological environment can not be ignored in the whole life cycle,although it creates significant value at the same time.In order to seek the purpose of "maximize the value, minimize the effect"of residential products,at first this paper need to balance the value creation and environmental impact,in the basis of the eco-efficiency theory puts forward the concept of life cycle carbon efficiency of residential product,it defined as the ratio of the value of the life cycle of residential products to carbon emissions. Then based on the theory of life cycle assessment,the lifecycle of residential product is divided into five stages:building materialsproduction,construction,occupation,demolition and dispositionof waste materials, the paper analyze the total carbon emissions of each phase make use of carbon emissions coefficient method,and established residential products carbon efficiency measurement model.Finally,propose the measures to improve the carbon efficiency of the residential product to realize the sustainable development.
\end{abstract}

\section{Introduction}

Residential products as a great demand for goods,the cumulativearea of residential construction and completion accountedfor the cumulative area of housing construction and completion more than $60 \%$ nearly ten years, whilethe proportion of energy consumption of residential products in various countries is basically maintained at around $1 / 3$, and the carbon emissions associated with these energy consumption also occupy a larger share ${ }^{[1]}$. Residential products have important value and the potential of energy saving and emission reduction,how to balance the relationship between the environmental impact and value creation of the residential products become a problem in our society.

\section{Quantification of the carbon efficiency of residential products}

\subsection{Life cycle carbon efficiencyof residential products}

The most commonly used method of ecological efficiencycalculating is the ratio of the impact methodat home and abroad, that is eco-efficiency=the value of product or service/environmental impact $^{[2]}$. In this paper,according to the concept of ecological efficiency, life cycle carbon efficiency of residential product is defined as the ratio of the value of the life cycle and carbon emissions of residential products, which reflects the value of residential products produced by unit carbon dioxide emissions are as follows:

$$
C E_{R B}=\frac{V_{R B}}{C_{R B}}(1)
$$

Among them, $C E_{R B}$ is the life cycle carbon efficiency, $C_{R B}$ and $V_{R B}$, respectively are the value of the life cycle and carbon emissionsof the residential products.

\subsection{Life cycle carbon emissions of residential products}

The paper based on the theory of life cycle assessment,the lifecycle of residentialproduct is divided into five stages: building materials production, construction, occupation,demolition and dispositionof waste materials ${ }^{[3]}$. Therefore,carbon emission of the total life cycle $C_{R B}$ can be estimated as follows:

$$
C_{R B}=C_{M}+C_{C}+C_{O}+C_{D}+C_{R}
$$


Among them, $C_{M}, C_{O}, C_{C}, C_{D}, C_{R}$ respectively represent building materials production, construction, occupation, demolition and dispositionof waste materials.

(1) Building materials production stage of residential products

The paper used the carbon emissions coefficient methodto calculate the carbon emissions of residential products. Carbon emission coefficient method is " $C=Q \times E F$ ", where $C, Q$ and $E F$, respectively represent the behalf of carbon emissions, carbon emissions and carbon emissions coefficient ${ }^{[4]}$.Building materials production Carbon emissions calculation method of building material production according to the formula (3), the carbon emission coefficient of common materials is also found in table 1.

$$
C_{M}=\sum_{i=1}^{n} m_{i} \times E F_{m, i} \times\left(1-S_{m, i}\right)
$$

Among them, $n$ is the total number of material, $m_{i}$ is the consumption of itype materials, $E F_{m, i}$ is carbon emissions coefficient of the itype material, $S_{m, i}$ is recycling coefficient of the $i$ typematerial, $i$ is the type of material.

Table 1 Carbon emission coefficients value of commonly used materials

\begin{tabular}{cccccc}
\hline Building material & unit & $E F_{m, i}$ & Building material & unit & $E F_{m, i}$ \\
\hline rebar & $\mathrm{tCO}_{2} / \mathrm{t}$ & 3.15 & Plywood & $\mathrm{tCO}_{2} / \mathrm{m}^{3}$ & 0.27 \\
cement & $\mathrm{tCO}_{2} / \mathrm{t}$ & 0.86 & Glass & $\mathrm{tCO}_{2} / \mathrm{t}$ & 1.40 \\
concrete & $\mathrm{tCO}_{2} / \mathrm{m}^{3}$ & 0.48 & Architectural coating & $\mathrm{tCO}_{2} / \mathrm{t}$ & 2.60 \\
cement mortar & $\mathrm{tCO}_{2} / \mathrm{m}^{3}$ & 0.40 & Polystyrene board & $\mathrm{tCO}_{2} / \mathrm{t}$ & 3.10 \\
clay brick & $\mathrm{tCO}_{2} / \mathrm{t}$ & 0.20 & PVC tube & $\mathrm{tCO}_{2} / \mathrm{t}$ & 4.70 \\
\hline
\end{tabular}

(2)Construction stage of residential products

Construction stage of carbon emissions including thecarbon emissions of building materials transportion from the origin to the construction siteand carbon emissions of residential construction. The carbon emissions generated by the transport process is seen in the formula (4):

$$
C_{C, T}=\sum_{i=1}^{n} m_{i} \times S_{i} \times E F_{t, i}
$$

Among them, $C_{C, T}$ iscarbon emissions in the transport process, $n$ is the total number of material, $m_{i}$ is the quality of $i$ type building materials, $S_{i}$ is the transport distance of $i$ materials, $E F_{t, i}$ is the carbon emissions coefficientof unit material transportunitdistance.

Residential construction process, the use of a variety of construction equipment will consume electricity, diesel and other energy,thus produce carbon emission,the calculation of its carbon emissions can be seen formula (5),carbon emission coefficient of common construction machinerysee table 2 .

$$
C_{C, M}=\sum_{i=1}^{n}\left(Q_{m, i} \times E F_{m, i}\right)
$$

Among them, $C_{C, M}$ is the carbon emission of construction, $n$ is the total number machinery, $Q_{m a c, i}$ is the $i$ machine-working day consumption, $E F_{m, i}$ is $i$ mechanical pump discharge coefficient. Table 2Carbon emission factors value of the common construction mechanical (8 h)

\begin{tabular}{ccccc}
\hline $\begin{array}{c}\text { Construction } \\
\text { machinery }\end{array}$ & Specifications & $\begin{array}{c}\text { Diesel } \\
(\mathrm{kg})\end{array}$ & $\begin{array}{c}\text { Electricity } \\
(\mathrm{kW} \cdot \mathrm{h})\end{array}$ & $\begin{array}{c}E F_{m, i}(\mathrm{~kg} / \text { machine-t } \\
\text { eam })\end{array}$ \\
\hline crawler dozer & $135 \mathrm{~kW}$ & 65.2 & - & 207.3 \\
truck & $6 \mathrm{t}$ & 32.2 & - & 102.4 \\
tower crane & $2000 \mathrm{KN} \cdot \mathrm{m}$ & - & 236.5 & 229.4 \\
butt-welder & $75 \mathrm{~kW}$ & - & 122.9 & 119.2 \\
concrete batching plant & $60 \mathrm{~m}^{3} / \mathrm{h}$ & - & 661.5 & 641.7 \\
air compressor & - & - & 215.0 & 208.6 \\
\hline
\end{tabular}

(3) Occupation stage of residential products

After the completion of the residential products, the operation of the relevant equipment will produce carbon emission. Related equipment includes heating, refrigeration, lighting, hot water supply, household appliances, etc.The paper mainly consider the necessary type of construction equipment, its carbon emissions mainly through the use of electricity and natural gas. 


$$
\mathrm{C}_{\mathrm{O}}=\left(Q_{e} \times E F_{e}+Q_{g} \times E F_{g}\right) \times N
$$

Among them, $Q_{e}$ is the electricity consumption for per year, $E F_{e}$ is the carbon emissioncoefficientof per unit electricity, $Q_{g}$ is annual natural gasconsumption, $E F_{g}$ is the carbon emissioncoefficient of per unit natural gas.

(4) Demolition stage of residential products

The demolition stage is estimating the energy consumption of different construction processes by formula (7):

$$
C_{D}=\sum_{i=1}^{n}\left(Q_{d, i} \times E F_{d, i}\right)
$$

Where $Q_{d, i}$ is the energy consumption of the demolition of the sub activities, $E F_{d, i}$ is the carbon emission coefficient of energy consumption.

(5) Dispositionof waste materials stage of residential products

The carbon emissions of dispositionof waste materials stageis from the waste materials processing and recycling, the calculation is as follow:

$$
C_{R}=\sum_{i=1}^{n}\left(m_{r, i} \times \eta_{r, i} \times E F_{r, i}\right)
$$

Among them, $m_{r, i}$ is the quality of recycled material, $\eta_{r, i}$ is the recovery ratio ofmaterial, $E F_{r, i}$ is the carbon emission coefficient of recycledmateria.

\subsection{Life cycle value of residential products}

The main and ultimate purpose of residential products is to provide the space for human life in a certain life, so the paper select the use value of housing to characterize its life cycle value ${ }^{[5]}$.The paper defines the use value of housing through the service life of residential products,building space. Therefore combined with the formula (1), the life cycle of residential products can be rewritten as the formula (9):

$$
C E_{R B}=\frac{S_{R B} \times H_{R B} \times L_{R B}}{C_{M}+C_{C}+C_{O}+C_{D}+C_{R}}
$$

Among them, $C E_{R B}$ is life cycle carbon efficiency of residential product, $S_{R B}$ is the construction area, $H_{R B}$ is thefloor height of residential building, $L_{R B}$ is the service life of residential products, other symbols significance.

\section{Calculation and analysis of residential products case}

This paper selects a high-rise residential building in Xi'an as an example, the construction area is $11257.51 \mathrm{~m}^{2}$,the building structure is shear wall structure,ground 27 ,the building height is $78.70 \mathrm{~m}$, the building orientation is north and south, the life cycle is 50 years.

Building materials production stage, the top 4 of carbon emissions in building materials is rebar, concrete, cement, cement mortar, which accounts for $62.5 \%$ of all building materials carbon emissions. During the construction stage, the transportation distance is assumed to be $50 \mathrm{~km}$, and the carbon emissions of the transportation process is 131.48t. According tothe project list of the mechanical equipment of the construction engineering,the use of electricity for $299196.76 \mathrm{kWh}$, with diesel fuel for $9737.80 \mathrm{~kg}$, so the total carbon emission is 321.19t. Residential use phase, according to the statistics of the residential products for 50 years with the carbon emissions of 1 508.13t, with an electric carbon emissions of 8 794.60t. So the total carbon emissions of residential use stage is 10302.73t. The removal and disposal of waste materials are approximately estimating.Specific informationare shown in table 3.

Table 3 The carbon emissions of residential products

\begin{tabular}{ccc}
\hline Life cycle stage & Carbon emission(t) & Proportion (\%) \\
\hline$C_{M}$ & 6528.35 & $37.1 \%$ \\
$C_{C}$ & 452.67 & $2.6 \%$ \\
$C_{O}$ & 10302.73 & $58.5 \%$ \\
$C_{R}$ & 273.01 & $0.3 \%$ \\
$C_{R B}$ & 17610.56 & $/$ \\
\hline
\end{tabular}


$C E_{R B}=\frac{S_{R B} \times H_{R B} \times L_{R B}}{C_{M}+C_{C}+C_{O}+C_{D}+C_{R}}=\frac{11257.51 \times 3 \times 50}{17610.56}=95.89 \mathrm{~m}^{3} \cdot \mathrm{a} / \mathrm{t} \quad(10)$

Can be seen from table 3,carbon emissions of occupationaccount for 58.5\%of the total carbon emissions, the contribution is in the first place. Second, building materials production stage, the proportion of $37.1 \%$, followed by construction stage $2.6 \%$, demolition of $1.6 \%$. Finally, as a waste processing stage of $0.3 \%$. To sum up by formula (10), the residential product case this paper proposed,its life cycle carbon efficiency for $95.89 \mathrm{~m}^{3} \cdot \mathrm{a} / \mathrm{t}$, can understand for per unitcarbon dioxide emissions produce life cycle value of residential product is 95.89 .

\section{Summary}

In this paper, the concept of the life cycle carbon efficiency of residential products is put forward,the case of a 27 story shear wall structure in Xi'an city is estimated. According to the calculation, the total carbon emissions of residential product life cycle is 17 610.56t, which the occupation stage isthe first account for $58.5 \%$ of the total,second is building materials production stage, the proportion is $37.1 \%$, followed by the construction stage $2.6 \%$, the demolition stage $1.6 \%$, the final waste treatment phase is $0.3 \%$.In summary,the life cycle carbon efficiencyof residential products is $95.89 \mathrm{~m}^{3} \cdot \mathrm{a} / \mathrm{t}$.

\section{References}

[1] Zhao Huizhen,Cheng Fei,Jin Ling,et al.Statistics Analysis on Development of China's Construction Industry in 2013[J].Journal of Engineering Management,(2014)No. 3,p.1-10.

[2] AiZhigang,ChengHuangping.Study on Eco-efficiency Evaluation Method of Green Building[J].Urbanism and Architecture,(2013)No. 16,p.137-138.

[3] D.Z. Li,H.X. Chen, Eddie C.M. Hui,et al.A methodology for estimating the life-cycle carbon efficiency of a residential building[J].Building and Environment,(2013)No. 59,p.448-455.

[4] Zhang Xiaocun,Wang Fenglai.Life-cycle assessment and control measures for carbon emissions of typical building in China[J].Building and Environment,(2015)No. 86,p.89-97.

[5] Li Dezhi,Li Qiming,Du Hui.Ecological footprint model of real estate development and its case analysis[J].Journal of Southeast UniversityNatural Science Edition,Vol. 38(2008)No. 4,p.732-735. 